\title{
Efficiency of the Schroth and Vojta Therapies in Adolescents with Idiopathic Scoliosis
}

\author{
Rață Marinela ${ }^{1 *}$ \\ Antohe Bogdan² \\ 1,2 “Vasile Alecsandri” University of Bacău, 157 Calea Mărășești, 600115, Romania
}

Keywords: scoliosis, idiopathic, adolescent, Vojta, Schroth

\begin{abstract}
Idiopathic scoliosis is one 3 of the most frequent spine diseases in adolescents. It is characterized by an inclination in the frontal plane of the vertebrae and a rotation in the transverse plane. This paper aims to demonstrate the efficiency of the Vojta and Schroth therapies for recovering the adolescents with scoliosis. The research was performed on three female subjects, aged between 11 and 13 years old. Following the assessment and individualized physical therapy programs, we can say that the originally established hypothesis was confirmed. The results demonstrated that the two forms of therapy are effective, obtaining 6 to 20-degree improvements in the Cobb angle.
\end{abstract}

\section{Introduction}

Idiopathic scoliosis is one of the most frequent spine diseases found among adolescents, especially girls. This is described as a deformity of the spine in the frontal plane of more than $10^{\circ}$ associated with a rotation (Lonstein, 1994). According to the Scoliosis Research Society, most cases of idiopathic scoliosis occur among adolescents. The age at which it occurs is between 10 and 18 and can be found in 4 out of 100 subjects (Josette et al., 2012). The incidence of idiopathic scoliosis is in $80-85 \%$ of cases, followed by the congenital type and finally by the neuromuscular type. Idiopathic scoliosis is sub-divided into: infantile scoliosis (up to 3 years), juvenile (between 3 and 10 years) and adolescent (for children older than 10 years) (Timothy, 2013). Most often, scoliosis is asymptomatic, making it difficult to be detected by parents or even by specialists.

The etiopathogenesis of scoliosis remains unknown, the researchers' attention has been lately directed towards the genetic cause of scoliosis, since $30 \%$ of adolescents diagnosed with scoliosis had a family history (Christopher, 2009). The genes responsible for the appearance of vertebral deformities have not been found yet, but much progress has been made in this respect. Other suppositions are:

\footnotetext{
*E-mail: marinela_rata@hotmail.com;
} 
involvment of growth hormone (GH), connective tissue diseases (especially for the collagen) or central nervous system, but not even these fully justify the onset of scoliosis (Lawrence, James \& Alto, 1998).

The scoliosis diagnosis can be made by radiographic examination or physical examination. The safest and most efficient way is the radiographic diagnosis followed by the Cobb angle calculation. The measurement consists of drawing two parallel lines, one on the top vertebra of the curve and the other on the lower vertebra. The Cobb angle results out of the intersection of the two lines (Jacqueline, Sanders \& Luhmann, 2012). For the physical examination, the best method to assess scoliosis is the Adam's forward bend test. In this test, the patient can be evaluated using the scoliometer to determine the degree of rotation of the vertebrae (Horne, Flannery \& Usman, 2014).

The therapeutic intervention depends on the severity of the scoliosis. In mild scoliosis (maximum 10 degrees) we usually intervene through physical therapy. If it exceeds 20 degrees, a corset is required, and if scoliosis exceeds 50 degrees, a surgical treatment is recommended (Bowen \& Delaware, 1996)

The Schroth method is a method for treating scoliosis in three dimensions. This emphasizes on the elongation of the spine, through breathing exercises performed in the corrective positions. These exercises are based on the sensorymotor, kinesthetic principles (the exercises being done from precorrective positions, using postural reflex activity) and exteroceptive (usually exercises are performed in front of a mirror). Through a selective contraction of the muscles of the trunk, patients are taught to control their airflow and redirect it to concave areas of the chest (Weiss, 2011). Following the positive results by using the Schroth method, this is practiced and recognized internationally.

The Vojta therapy addresses the reflex locomotion capacities by stimulating the inborn movement patterns. The author argues that the reflex movement can be obtained from three basic positions: supine, prone and lateral decubitus. In order to stimulate the reflex movement patterns, there are 10 stimulation areas on the body, arms and legs (Bauer, Appaji \& Mundt, 1992).

Currently, the literature considers the Vojta and Schroth therapies as the best methods for treating idiopathic scoliosis (Steffan, 2015). If they are associated with the orthopedic treatment (corset), the results will soon occur. By means of the Vojta and Schroth therapies, some authors report improvements in the Cobb angle of 10 to 15 degrees in one year (Kuru et al., 2015).

\section{Material and methods}

The hypothesis we started from was the following: applying a treatment scheme based on the exercises from the Schroth and Vojta therapy will improve the patients' posture and give a better functionality of the spine.

The research methods used were the following: the theoretical documentation method, the measurement and evaluation method, the observation method, the graphical method, the data recording method and the case study method.

The research was conducted in the laboratory of sensory stimulation from the 
physical therapy rehabilitation facility at "Vasile Alescandri" University of Bacau and at the subjects' homes. We had three female subjects, aged between 11 and 13 years old, diagnosed with idiopathic scoliosis.

Table 1. Subjects of the experiment

\begin{tabular}{|c|c|c|c|c|c|}
\hline $\begin{array}{l}\text { Crt. } \\
\text { No. }\end{array}$ & $\begin{array}{l}\text { Surname } \\
\text { and name }\end{array}$ & Sex & Age & Clinical diagnosis & $\begin{array}{l}\text { Type of scoliosis } \\
\text { (according to } \\
\text { Schroth) }\end{array}$ \\
\hline 1 & D.E. & $\mathrm{F}$ & 12 years & $\begin{array}{c}\text { Thoracolumbar scoliosis } \\
540 \text { left, } 70 \text { rotation }\end{array}$ & $4 \mathrm{~B}$ \\
\hline 2 & D.F. & $\mathrm{F}$ & 12 years & $\begin{array}{l}\text { Thoracic scoliosis } 460 \\
\text { right, } 100 \text { rotation }\end{array}$ & $4 \mathrm{~B}$ \\
\hline 3 & I.A. & $\mathrm{F}$ & 12 years & $\begin{array}{c}\text { Thoracic scoliosis } 260 \\
\text { right, } 50 \text { rotation }\end{array}$ & 4B \\
\hline
\end{tabular}

The evaluation consisted in: visual examination and palpation, radiological examination, Cobb angle and vertebral rotation.

Following the evaluation, the functional diagnosis was introduced: limitation of the mobility of the dorsal and lumbar spine, deviations of the spinal curve in sagittal and frontal plane, presence of pain during the day, hypertonia of the trunk muscles on the rotation side, changes of the symmetry of the chest and decrease of its elasticity, changes in the respiratory mechanics, asymmetry of the shoulder and pelvic girdle.

The physical therapy intervention was personalized for each patient and consisted in:

Subject no. 1 D.E: Schroth therapy: axial stretching, stool kyphosis, standing muscular wrapping, side-lying wrapping, muscle kyphosis on the ball.

Vojta therapy: first position in Vojta, second phase of the rolling, sitting lying.

Subject no.2 D.F: Schroth therapy: axial stretching, stool kyphosis, standing muscular wrapping, side-lying wrapping, kyphosis on the ball.

Vojta therapy: first position in Vojta, second phase of the rolling, sitting lying

Subject no.3 I.A: Schroth therapy: axial stretching, standing muscular wrapping, side-lying wrapping, hip band isometry, stool kyphosis.

Vojta therapy: first position in Vojta, second phase of the rolling, reflex crawling with three points of support.

Each exercise in the Schroth therapy was repeated 10 times in series of 5. For one month the patients did the exercises under the supervision of a physiotherapist in his office, and after they learned, they practised them at home without supervision. All patients wore a corset 23 hours a day and did the exercises daily.

The Vojta positions were repeated twice on each side (left / right), for 60 seconds. The frequency of meetings was 2 per week. 


\section{Results and Discussions}

Table 2. Assesment of subject no. 1

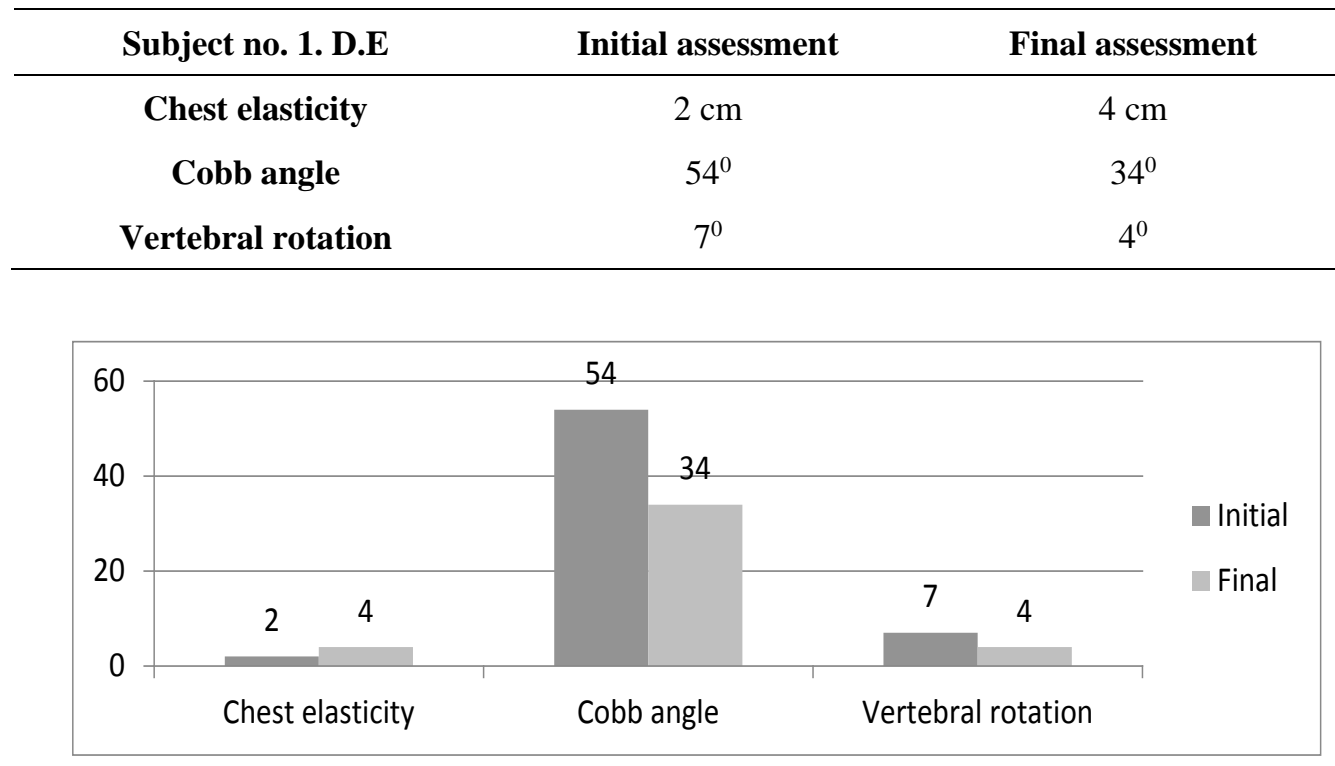

Figure 1. Evolution of results for subject no. 1

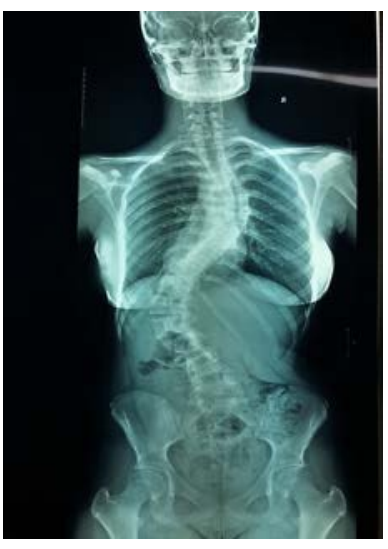

Figure 2. Frontal radiography

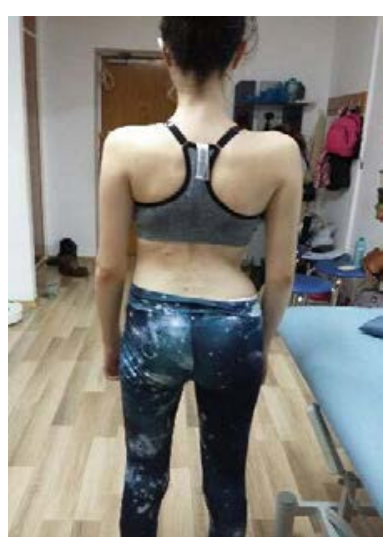

Figure 3. Before therapy

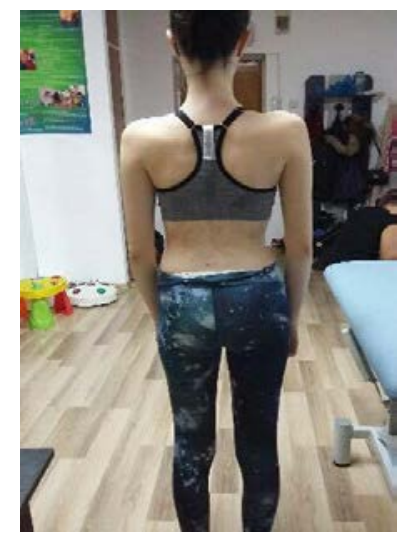

Figure 4. After therapy

Table 3. Assesment of subject no.2

\begin{tabular}{ccc}
\hline Subject no. 2. D.F & Initial assessment & Final assessment \\
\hline Chest elasticity & $3 \mathrm{~cm}$ & $4 \mathrm{~cm}$ \\
Cobb angle & $26^{0}$ & $20^{0}$ \\
Vertebral rotation & $5^{0}$ & $2^{0}$ \\
\hline
\end{tabular}




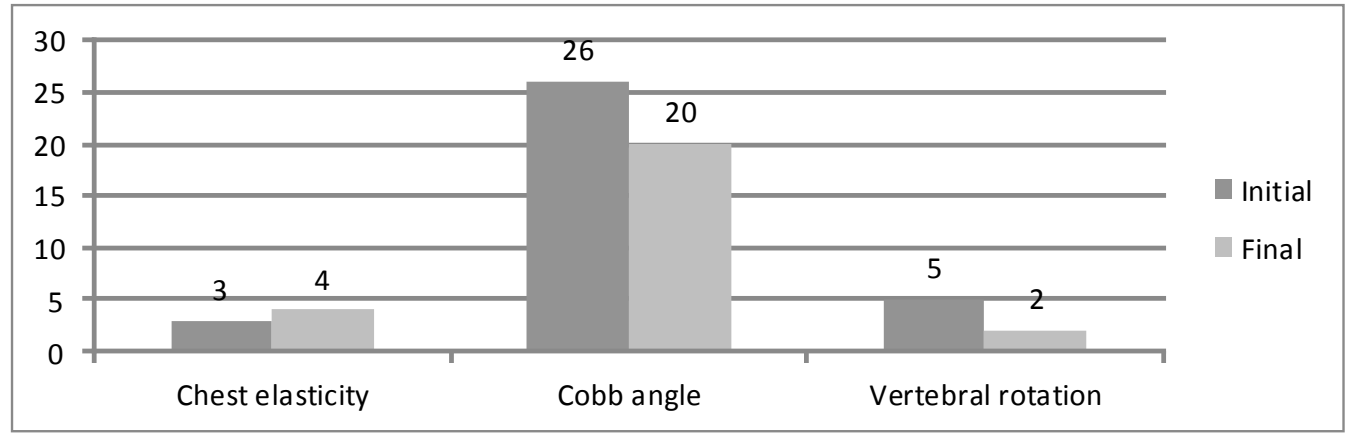

Figure 5. Evolution of results for subject no. 2

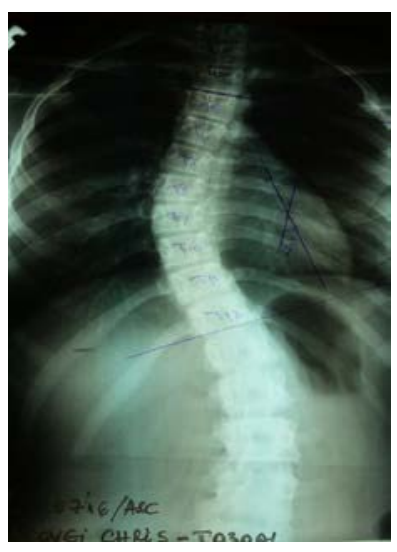

Figure 6. Frontal radiography

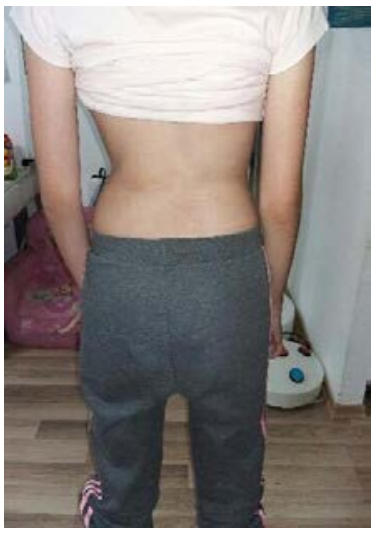

Figure 7. Before therapy

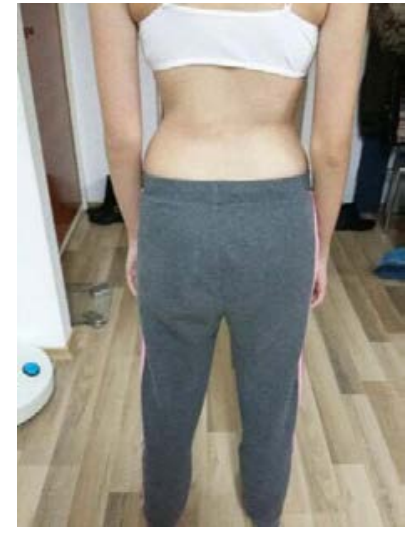

Figure 8. After therapy

Table 4. Assessment of subject no. 3

\begin{tabular}{ccc}
\hline Subject no. 3. I.A & Initial assessment & Final assessment \\
\hline Chest elasticity & $2 \mathrm{~cm}$ & $5 \mathrm{~cm}$ \\
Cobb angle & $46^{0}$ & $34^{0}$ \\
Vertebral rotation & $13^{0}$ & $7^{0}$ \\
\hline
\end{tabular}




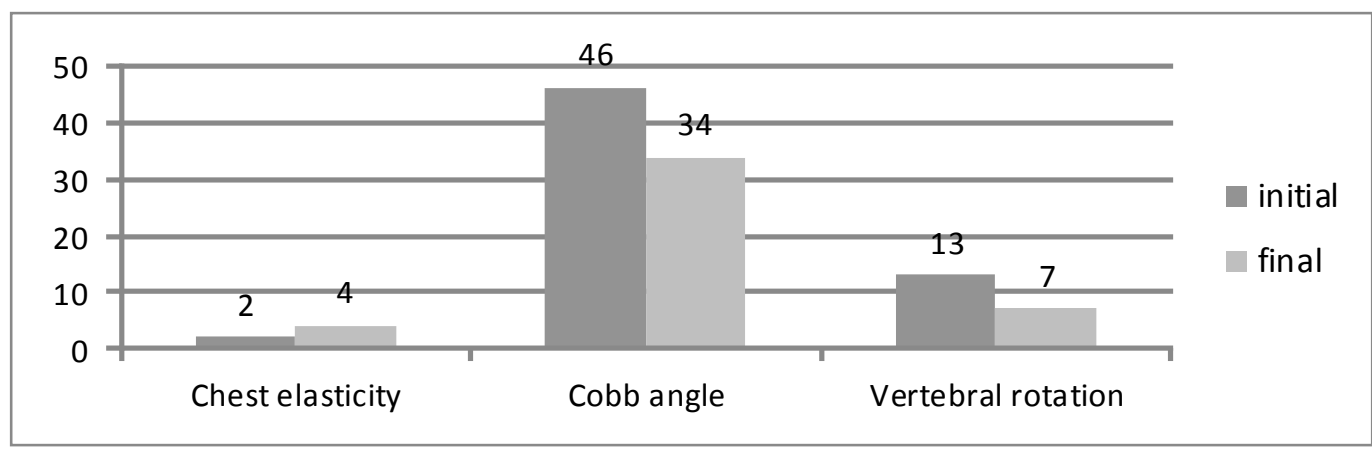

Figure 9. Evolution of results for subject no. 3

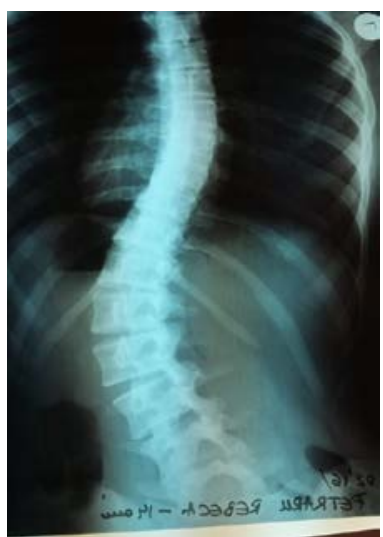

Figure 10. Frontal radiography

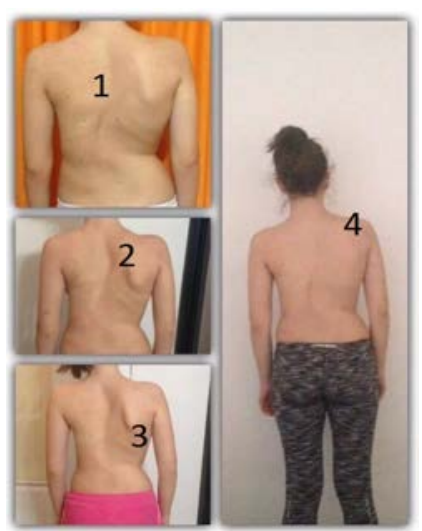

Figure 11. Before and after therapy

In the chart no.1, we highlighted the biggest improvement of the Cobb angle, 20 degrees (54 initial - 34 final). We can also notice an increase of the chest elasticity and a decrease of the vertebral rotation, but not as obvious as the Cobb angle.

Chart no. 2 shows a very good evolution of the patient, with a decrease of the Cobb angle by 6 degrees ( $26^{\circ}$ initial $-20^{\circ}$ final). The vertebral rotation almost disappeared and the chest elasticity increased by $1 \mathrm{~cm}$ from the initial value.

Chart no. 3 shows an improvement of the Cobb angle by 12 degrees $\left(46^{0}\right.$ initial $-34^{0}$ final) and a better evolution with regard to the vertebral rotation. The chest elasticity doubled compared to the initial value.

In all patients, we obtained a decrease of the Cobb angle and an improved chest elasticity directly proportional with the overcome degrees. The improvement of the Cobb angle values led to an improved mechanics of the chest and the spine regained the compliance ability, thus improving the chest elasticity values.

Neither at the beginning nor at the end of the recovery programme were found any connections between the vertebral rotation and the Cobb angle. It seems that the rotation is not influenced by the deviation in the frontal plane, because 
subject no. 1 whose deviation in the frontal plane is greater, has a lower vertebral rotation than the subject no. 3 whose deviation in the frontal plane is 2 times lower.

Along with the Cobb angle, the vertebral rotation can improve the chest mechanics through the direct relationship between the vertebrae and ribs. Therefore, the rotation will cause the rotation of the vertebrae and ribs and will result in a change of the respiratory biomechanics.

All the results confirm that scoliosis is a pathology in three dimensions of the spine and proves that the body is a whole. Any local dysfunction can affect the body balance globally and the adolescent with scoliosis often happen to present other disorders such as foot, knee, hip etc. deviations.

\section{Discussions}

As a result of a applied therapeutic protocol, we obtained a decreased of Cobb angle with an average value of 12 degrees, while the angle of rotation had a decrese of $4^{0}$, the results being comparable to the values raportated in the literature. In 1992 following a protocol based on the Schroth therapy exercises, Weiss obtained an improvement of $5^{0}$ degrees of Cobb angle. Two decades later, Kuru applied a therapeutic protocol based on exercises from Schroth therapy, the author reporting an improvement of $2.5^{\circ}$ in the Cobb angle and $4.2^{\circ}$ in the angle of rotation. Using a multidisciplinary approach (breathing exercises, postural rehabilitation and Schroth therapy exercises), Pugacheva (2012) achieved an improvement in the Cobb angle of 12 degrees. Along with Schroth and Vojta therapies is also recommended to performing exercise programs. Even though they are not as effective as the two methods mentioned aboved, they also can stop the development of vertebral deformities.

Following the results, Schroth and Vojta therapies, along with orthopedic corset therapy, have proven to be very effective in treating scoliosis.

\section{Conclusions}

By analyzing the results collected during the research, we can say that the initially-established hypothesis was confirmed, a claim that is supported by the following conclusions:

- As a result of complying with the specific methodology for spine assessment and of the measurements taken, we can say the spine dysfunctions have been clearly identified;

- By applying the Vojta and Schroth methods, we managed to reduce a painful symptom and to decrease the degrees of the existing scoliosis;

- All these were possible due to a strict compliance with the directions provided by the physical therapist and the ongoing application of the recovery program. The treatment success relates to the subjects' awareness of the causes which determined the pathology and to their avoidance for preserving the obtained results;

- The ongoing application of the presented program can have very good effects in both the treatment and prophylaxis of spine deficiencies in adolescents. 


\section{References:}

1. BAUER, H., APPAJI, G., \& MUNDT, D. (1992). Vojta neurophysiologic therapy, The indian journal of pediatrics, 1(59): 37-51;

2. BOWEN, R., \& DELAWARE, W. (1996). Adolescent Idiopathic Scoliosis: Treatment with the Wilmington Brace. A Comparison of Full-Time and PartTime Use, J Bone Joint Surg Am., 78 (7): 1056 -62;

3. CHRISTOPHER, R. (2009). The Genetic Basis of Adolescent Idiopathic Scoliosis, Journal of The Spinal Research Foundation, 1(4);

4. HORNE, J., FLANNERY, R., \& USMAN, S. (2014). Adolescent Idiopathic Scoliosis: Diagnosis and Management, American Family Physician, 3(89);

5. JACQUELINE, C., SANDERS, J., \& LUHMANN, J. (2012). Reliability of Radiographic Measures for Infantile Idiopathic Scoliosis, J. Bone Joint Surg. Am., 20, 94(12);

6. JOSETTE, B., COOK, T., RIGO, M., DE MAUROY, J., ROMANO, M., NEGRINI, S., DURMALA, J., CAMPO, A., COLLIARD, C., M'HANGO, A., \& BIALEK, M. (2012). Physical Therapy for Adolescents with Idiopathic Scoliosis, Physical Therapy Perspectives in the 21st Century - Challenges and Possibilities, Middlesbrough: ed. InTech;

7. KURU, T., YELDAN, I., DERELI, EE., OZDINCLER, AR., DIKICK, F., \& COLAC, J. (2015). The efficacy of three-dimensional Schroth exercises in adolescent idiopathic scoliosis: A randomised controlled clinical trial, Clinical Rehabilitation, 30(108);

8. LAWRENCE, A., JAMES G., \& ALTO, P. (1988). Adolescent idiopatic scoliosis, The Western Journal Of Medicine, 148: 182-191;

9. LONSTEIN, J. (1994). Adolescent idiopathic scoliosis, The Lancet, 344: 14071412 ;

10. PUGACHEVA, N. (2012). Corrective exercises in multimodality therapy of idiopathic scoliosis in children - analysis of six weeks efficiency - pilot study. Studies in Health Technology and Informatics, 176: 365-371;

11. STEFFAN, K. (2015). Physical therapy for idiopatic scoliosis, Der Orthopäde, 44: 852-858;

12. TIMOTHY, H. (2013). Idiopathic Scoliosis in Adolescents, New England Journal of Medicine, 368: 834-41;

13. WEISS, R. (1992). Idiopathic Scoliosis under the Influence of a Physiotherapy Rehabilitation Programme, Physiotherapy, 78(11): 815-821;

14. WEISS, R. (2011). The method of Katharina Schroth - history, principles and current development, Scoliosis, 6 (17). 


\title{
Eficiența Terapiilor Schroth și Voijta la Adolescenții cu Scolioză Idiopatică
}

\author{
Rață Marinela ${ }^{1}$ \\ Antohe Bogdan ${ }^{2}$ \\ 1,2Universitatea „Vasile Alecsandri” din Bacău, Calea Mărășești 157, 600115, România
}

Cuvinte cheie: scolioză, idiopatică, adolescenți, Vojta, Schroth

\section{Rezumat}

Idiopathic scoliosis is one 3 of the most frequent spine diseases in adolescents. It is characterized by an inclination in the frontal plane of the vertebrae and a rotation in the transverse plane. This paper aims to demonstrate the efficiency of the Vojta and Schroth therapies for recovering the adolescents with scoliosis. The research was performed on three female subjects, aged between 11 and 13 years old. Following the assessment and individualized physical therapy programs, we can say that the originally established hypothesis was confirmed. The results demonstrated that the two forms of therapy are effective, obtaining 6 to 20-degree improvements in the Cobb angle.

\section{Introducere}

Scolioza idiopatică este una din cele mai dese afecțiuni ale coloanei vertebrale întâlnite în rândul adolescenților, în special la fete. Aceasta este descrisă drept o diformitate a coloanei vertebrale în plan frontal, de peste $10^{0}$, asociată cu o rotație (Lonstein, 1994). Conform societății de cercetare a scoliozei, cele mai multe cazuri de scolioză idiopatică apar în rândul adolescenților. Vârsta la care apare este între 10 și 18 ani, și poate fi găsită la 4 din 100 de subiecți (Josette et al., 2012). Incidența scoliozei idiopatice este de $80-85 \%$ din cazuri, urmată de cea congenitală și în cele din urmă de cea neuromusculară. Scolioza idiopaică este subclasificată în: scolioză infantilă (până în 3 ani), juvenilă (între 3 și 10 ani) și adolecentă (pentru copii mai mari de 10 ani) (Timothy, 2013). De cele mai multe ori, scolioza este asimpomatică, fiind astfel greu de depistat de către părinți sau chiar de către specialiști.

Etiopatogenia scoliozei rămâne încă necunoscută, în ultimul timp atenția cercetătorilor a fost îndreptată spre cauza genetică a scoliozei, deoarece $30 \%$ dintre adolescenții depistați aveau antecedente familiare (Christopher, 2009). Genele responsabile de apariția diformităților vertebrale nu au fost găsite, dar se fac mari progrese în acest sens. Alte ipoteze sunt: implicarea hormonilor de creștere $(\mathrm{GH})$, afecțiuni ale țesutului conjunctiv (în special ale colagenului) sau ale sistemului nervos central, însă nici acestea nu justfică în totalitate apariţia scoliozei (Lawrence, James \& Alto, 1998).

Diagnosticarea scoliozei se poate face prin examinare radiografică sau prin examenul fizic. Cea mai sigură și eficientă metodă de diagnosticare este examenul radiografic, urmat de calcularea unghiului Cobb. Măsurătoarea constă în trasarea a 
două linii paralele, una pe vertebra superioară curburii și cealaltă pe vertebra inferioară. Din intersecția celor 2 linii rezultă unghiul Cobb (Jacqueline, Sanders \& Luhmann, 2012). Pentru examenul fizic, cea mai bună metodă de evaluare a scoliozei este testul Adam de flexie anterioară. În cadrul acestui test pacientul poate fi evaluat cu ajutorul scoliometrului, pentru a stabili gradul de rotație a vertebrelor (Horne, Flannery \& Usman, 2014).

În funcție de gravitatea scoliozei avem și intervenția terapeutică. De obicei, în scoliozele ușoare (maxim 10 grade) se intervine prin kinetoterapie. Dacă se depășesc 20 de grade se impune corset, iar dacă scolioza depășește 50 de grade se recomandă tratamentul chirurgical (Bowen \& Delaware, 1996).

Metoda Schroth este o metodă de tratament a scoliozei în 3 dimensiuni. Aceasta pune accentul pe elongația coloanei vertebrale, prin exerciţii de respirație efectuate în poziții corective. La baza acestor exerciții stau principii senzoriomotrice, kinestezice (exercițiile fiind făcute din poziții precorective, cu ajutorul activității reflexe posturale) și exteroceptive (de obicei, exercițiile se fac în oglindă). Prin contracția selectivă a musculaturii trunchiului, pacienții sunt învățați să își controleze fluxul de aer și să îl redirecționeze spre zonele concave ale cutiei toracice (Weiss, 2011). Ca urmare a rezultatelor pozitive obținute cu ajutorul metodei Schroth, aceasta este practicată și recunoscută la nivel internaţional.

Terapia Vojta se adresează capacităților de locomoție reflexă, prin stimularea modelelor născute de mișcare. Autorul susține că mișcarea reflexă poate fi obținută din 3 poziții fundamentale: decubit dorsal, decubit ventral și decubit lateral. Pentru a stimula patternurile de mișcare reflexă, există 10 zone stimulare la nivelul corpului, brațelor și picioarelor (Bauer, Appaji \& Mundt, 1992).

În momentul de față, literatura de specialitate consideră terapile Vojta şi Schroth cele mai bune metode de tratament al scoliozei idiopatice (Steffan, 2015), iar dacă acestea sunt completate de tratamentul ortopedic (corset), rezultatele nu vor întârzia să apară. $\mathrm{Cu}$ ajutorul terapiilor Vojta și Schroth, unii autori relatează îmbunătățiri ale unghiului Cobb de 10-15 grade într-un an (Kuru et al., 2015).

\section{Material și metode}

Ipoteza de la care am plecat a fost următoarea: dacă aplicarea unei scheme de tratament bazate pe exercții din terapia Schroth și Vojta va duce la îmbunătățirea posturii pacienților și la o mai bună funcționalitate a coloanei vertebrale.

Metodele de cercetare folosite au fost: metoda documentării teoretice, metoda măsurării și evaluării, metoda observației, metoda grafică, metoda înregistrării datelor, metoda studiului de caz.

Cercetarea s-a desfăşurat în laboratorul de stimulare senzorială din baza de recuperare prin kinetoterapie a Universităţii Vasile Alescandri din Bacău și la domiciliu subiecților.

Studiul s-a realizat pe 3 subiecți, de sex feminin, cu vârste cuprinse între 11 și 13 ani, diagnosticați cu scolioză idiopatică. 
Tabel 1. Subiecții cuprinși în experiment

\begin{tabular}{cccccc}
\hline $\begin{array}{c}\text { Nr. } \\
\text { Crt. }\end{array}$ & $\begin{array}{c}\text { Nume și } \\
\text { prenume }\end{array}$ & Sex & Vârsta & Diagnostic clinic & $\begin{array}{c}\text { Tipul de scolioză } \\
\text { (după Schroth) }\end{array}$ \\
\hline $\mathbf{1}$ & D.E & F & 12 ani & $\begin{array}{c}\text { Scolioză toraco-lombară } 54^{0} \\
\text { stânga, } 7^{0} \text { de rotație. } \\
\text { Scolioză toracală dreapta } \\
46^{0}, 10^{0} \text { rotație. }\end{array}$ & $3 \mathrm{~B}$ \\
$\mathbf{2}$ & D.F & F & 13 ani & $\begin{array}{c}\text { Scolioză toracală dreapta } \\
26^{0}, 5^{0} \text { de rotație. }\end{array}$ & $3 B$ \\
\hline
\end{tabular}

Evaluarea a constat în: examenul vizual și palpator, examenul radiologic, elasticitatea toracică, unghiul Cobb și rotația vertebrală.

În urma evaluării, diagnosticul funcțional a fost: limitarea mobilităţii coloanei vertebrale dorsale și lombare, deviații ale curburilor coloanei în plan sagital și frontal, prezenta durerilor în timpul zilei, hipertonia musculaturii trunchiului de partea $\mathrm{cu}$ rotația, modificări de simetrie la nivelul toracelui și diminuarea elasticităţii acestuia, modificări ale mecanicii respiratorii, asimetrie între centurile scapulare și pelvine.

Intervenția kinetoterapeutică a fost personalizată pentru fiecare pacient și a constat în:

Subiectul nr. 1 D.E: Terapia Schroth: întindere axială, cifozare cu scăunel, manta musculară în ortostatism, manta din culcat lateral, cifozare musculară pe minge. Terapia Vojta: prima poziție din Vojta, faza a 2-a a rostogolirii, așezat lung.

Subiectul nr. 2 D.F: Terapia Schroth: întindere axială, cifozare cu scăunel, manta musculară în ortostatism, manta din culcat lateral, cifozare pe minge.

Terapia Vojta: prima poziție din Vojta, faza a 2-a a rostogolirii, așezat lung.

Subiectul nr. 3 I.A: Terapia Schroth: întindere axială, manta musculară în ortostatism, manta musculară din culcat lateral, izometrie cu banda pe șold, cifozare cu scăunel. Terapia Vojta: prima poziție din Vojta, faza a 2-a a rostogolirii, târârea reflexă cu 3 puncte de sprijin.

Fiecare exercițiu din cadrul terapiei Schroth a fost repetat de 10 ori, în serii de câte 5. Timp de 1 lună, pacienții au făcut exercițiile la cabinet, sub supravegherea kinetoterapeutului, iar după ce le-au învățat, au fost făcute acasă, fără supraveghere. Toți pacienții au purtat corset 23 de ore pe zi și au făcut exercițiile zilnic.

Pozițiile din Vojta s-au repetat de 2 ori pe fiecare parte (stânga/dreapta), câte 60 de secunde. Frecvența ședințelor a fost de 2 pe săptămână. 


\section{Rezultate și discuții}

Tabel 2. Evaluare subiect $n r .1$

\begin{tabular}{ccc}
\hline Subiectul nr. 1. D.E & Evaluare inițială & Evaluare finală \\
\hline Elasticitatea toracică & $2 \mathrm{~cm}$ & $4 \mathrm{~cm}$ \\
Unghiul Cobb & $54^{0}$ & $34^{0}$ \\
Rotația vertebrală & $7^{0}$ & $4^{0}$ \\
\hline
\end{tabular}

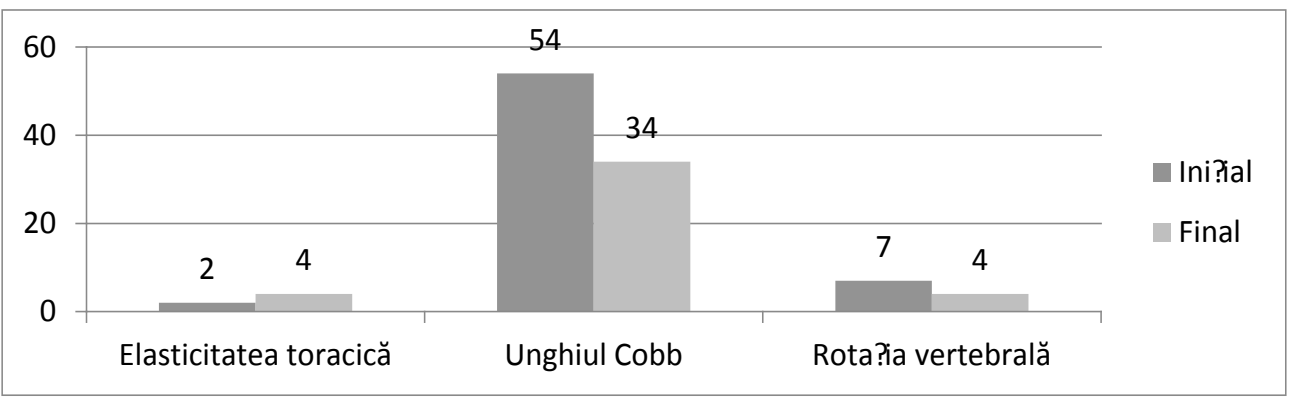

Figura 1. Evoluția rezultatelor pentru subiectul nr. 1

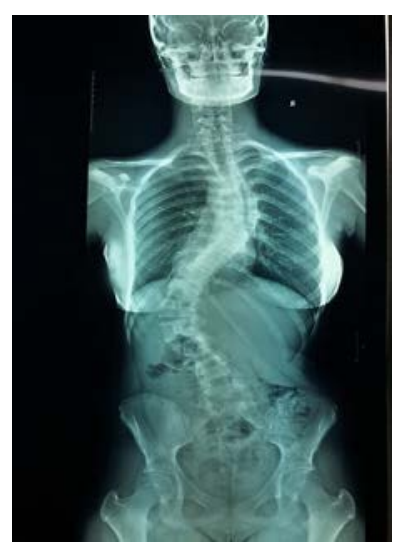

Figura 2. Radiografie frontală

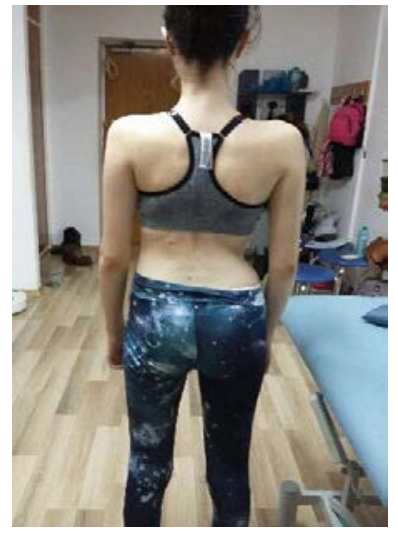

Figura 3. Inainte de terapie

Tabel 3. Evaluare subiect $n r .2$

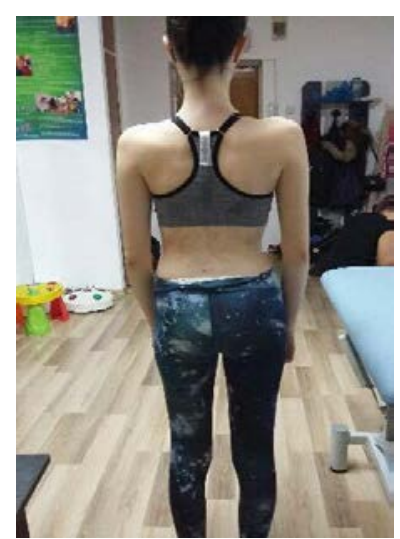

Figura 4. După terapie

\begin{tabular}{ccc}
\hline Subiectul nr. 2. D.F & Evaluare inițială & Evaluare finală \\
\hline Elasticitatea toracică & $3 \mathrm{~cm}$ & $4 \mathrm{~cm}$ \\
Unghiul Cobb & $26^{0}$ & $20^{0}$ \\
Rotația vertebrală & $5^{0}$ & $2^{0}$ \\
\hline
\end{tabular}




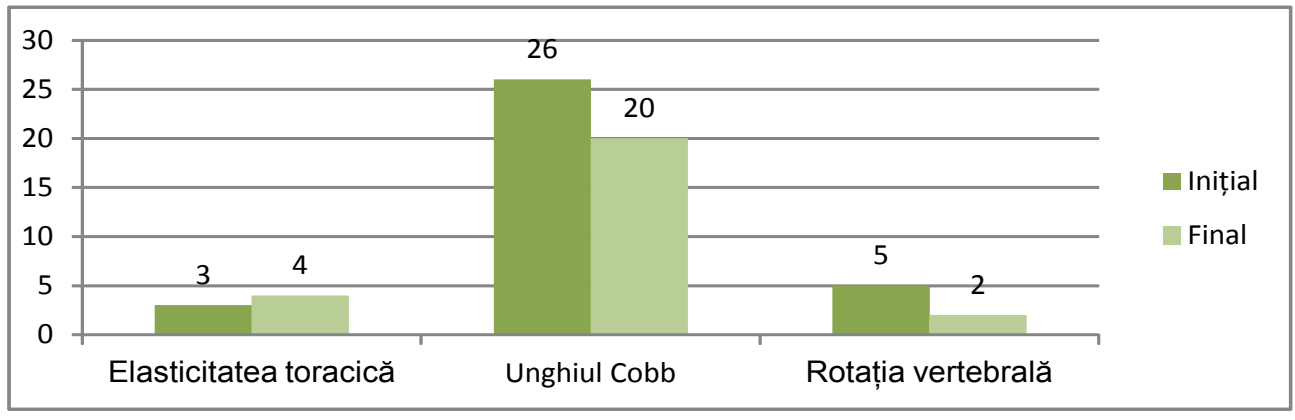

Figura 5. Evoluția rezultatelor pentru subiectul nr.2

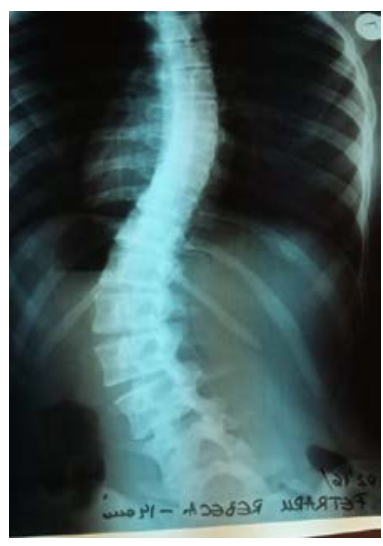

Figura 6. Radiografie frontală
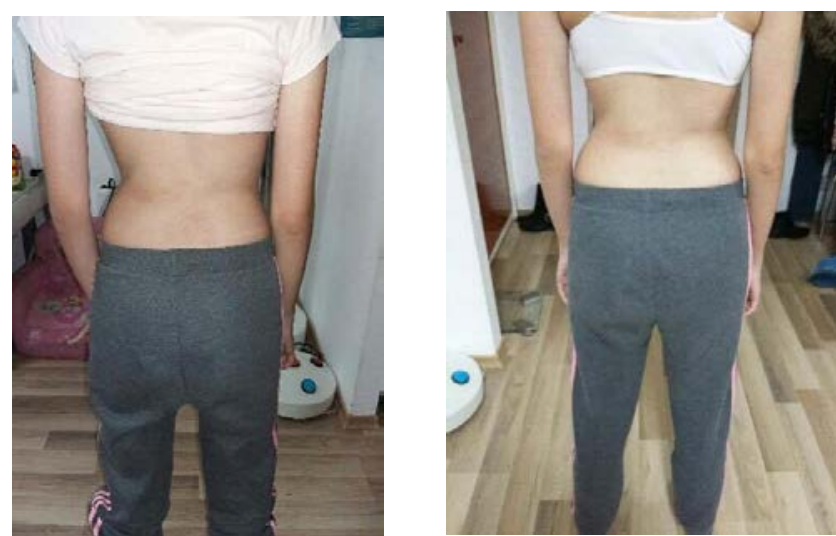

Figura 7. Inainte de terapie Figura 8. După terapie

Tabel 4. Evaluare subiect nr. 3

\begin{tabular}{ccc}
\hline Subiectul nr. 3. I.A & Evaluare inițială & Evaluare finală \\
\hline Elasticitatea toracică & $2 \mathrm{~cm}$ & $5 \mathrm{~cm}$ \\
Unghiul Cobb & $46^{0}$ & $34^{0}$ \\
Rotația vertebrală & $13^{0}$ & $7^{0}$ \\
\hline
\end{tabular}

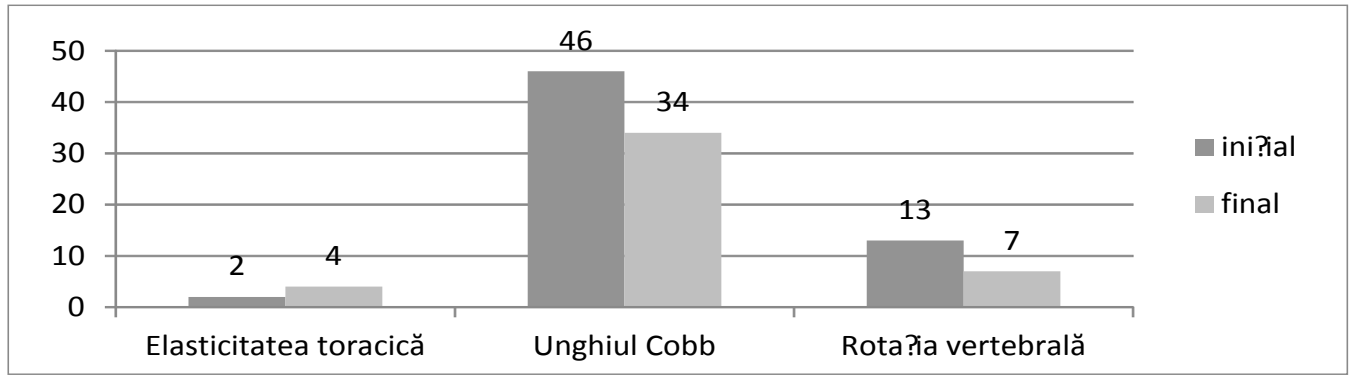

Figura 9. Evoluția rezultatelor pentru subiectul nr. 3 


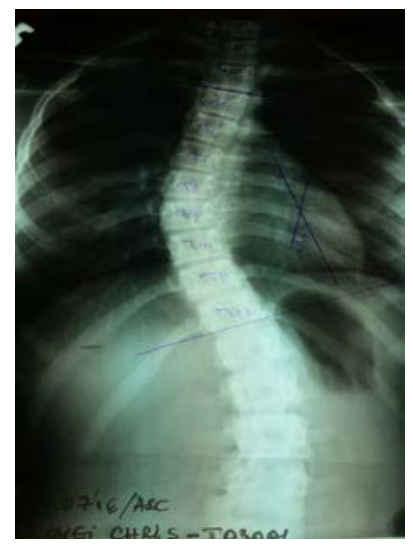

Figura 10. Radiografie frontală

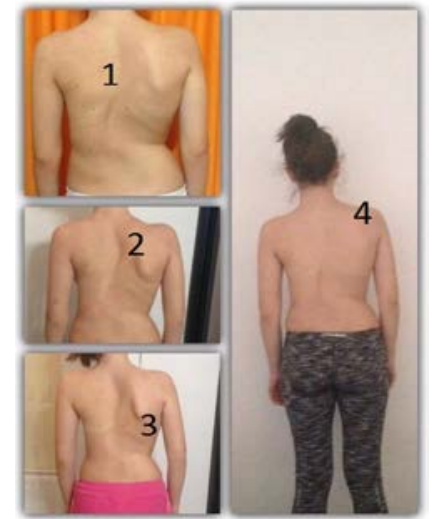

Figura 11. Inainte și după tratament

În graficul 1 avem evidențiată cea mai mare îmbunătățire a unghiului Cobb, 20 de grade ( $54^{0}$ iniţial $-34^{0}$ final). De asemenea, observăm creșterea elasticităţii cutiei toracice și diminuarea rotației vertebrale, însă nu atât de evidentă precum cea a unghiului Cobb.

Graficul nr. 2 prezintă o evoluție foarte bună a pacientului, cu o diminuare a unghiului Cobb de 6 grade $\left(26^{0}\right.$ inițial $-20^{0}$ final). Rotația vertebrală aproape a dispărut, iar elasticitatea toracală a crescut cu $1 \mathrm{~cm}$ față de valoare inițială.

Graficul nr. 3 prezintă o îmbunătătire a unghiului Cobb cu 12 grade $\left(46^{0}\right.$ iniţial $-34^{0}$ final) și o evoluție mai bună în ceea ce privește rotația vertebrală. Elasticitatea toracică s-a dublat comparativ cu valoarea inițială.

La toți pacienții am obținut o diminuare a unghiului Cobb și o îmbunătătire a elasticităţii toracice direct proporțională cu gradele câștigate. Îmbunătăţirea valorilor unghiului Cobb a dus la îmbunătățirea mecanicii cutiei toracice și a redat capacitatea de complianță a coloanei vertebrale, îmbunătățind astfel valorile elasticităţii toracice.

Nici la începutul și nici la sfârșitul programului de recuperare nu au fost găsite legături în ceea ce privește rotaţia vertebrală şi unghiul Cobb. Se pare că rotația nu este condiționată de deviația în plan frontal, deoarece subiectul 1 la care deviaţia în plan frontal este mai mare, are o rotație vertebrală mai mică față de subiectul 3, la care deviația în plan frontal este de 2 ori mai mică.

Alături de unghiul Cobb, rotația vertebrală poate contribui la îmbunătăţirea mecanicii cutiei toracice prin relația directă dintre vertebre și coaste. Așadar, rotația vertebrelor va determina rotația coastelor și va avea drept rezultat modificarea biomecanicii respiratorii.

Toate rezultatele obținute confirmă faptul că scolioza este o patologie în 3 dimensiuni a coloanei vertebrale și demonstrează că organismul este un întreg. Orice disfuncție locală poate afecta echilibrul organismului la nivel global și deseori se întâmplă ca adolescenții scoliotici să prezinte și alte afecțiuni precum deviații de picior, genunchi, șold etc. 


\section{Discuții}

$\mathrm{Ca}$ urmare a protocolului terapeutic aplicat am obținut diminuarea unghiului Cobb cu o valoare medie de $12^{0}$, în timp ce unghiul rotație a avut o scădere de $4^{0}$, rezultatele înregistrate fiind comparabile cu valorile raportate în literatura de specialitate.

În anul 1992, în urma unui protocol bazat pe exerciții din terapia Schroth, Weiss a obținut o îmbunătățirie a unghiului Cobb de $5^{0}$. Două decenii mai târziu, (Kuru et al., 2015) a aplicat de asemenea un protocol terapeutic bazat pe exercitii din terapia Schroth, autorul raportând o îmbunătățire de $2,5^{\circ}$ a unghiului Cobb și de $4,2^{0}$ a unghiului de rotație.

Folosind o abordare multidisciplinară (exerciții de respirație, reeducare posturală și exerciții din terapia Schroth), Pugacheva (2012) a obținut o îmbunătățire a unghiului Cobb de $12^{0}$. Alături de terapiile Schroth și Vojta, literatura de specialitate recomandă și efectuarea programelor de exerciţii fizice. Chiar dacă acestea nu sunt la fel de eficiente ca și cele 2 metode amintite mai sus, ele pot opri evoluția deformațiilor coloanei vertebrale.

În urma rezultatelor obținute, terapiile Schroth și Vojta, împreună cu tratamentul ortopedic prin corset, s-au dovedit a fi foarte eficiente în tratamentul scoliozei.

\section{Concluzii}

Analizând rezultatele obținute în urma desfășurării cercetării putem afirma că ipoteza stabilită initial a fost confirmată, afirmație ce este susținută de următoarele concluzii:

- Ca urmare a respectării metodologiei specifice de evaluare a coloanei vertebrale și a măsurătorilor efectuate putem spune că au fost identificate cu exactitate disfuncțiile coloanei vertebrale;

- Prin aplicarea metodelor Schroth și Vojta, am reușit o reducere a simptomatologiei algice și o diminuare a gradelor scoliozelor existente;

- Toate aceste aspecte au fost posibile ca urmare a respectării cu strictețe a indicațiilor oferite de către kinetoterapeut și aplicarea continuă a programului de recuperare. Succesul terapeutic ține de conștientizarea subiecților a cauzelor care au determinat aparția patologiei și evitarea acestora pentru conservarea rezultatelor obținute;

- Aplicarea continuă a programului prezentat poate avea efecte foarte bune atât în tratamentul cât și în profilaxia deficiențelor coloanei vertebrale la adolescenți. 